\title{
Utility of a Cucumber Plant Bioassay to Assess Fungicide Efficacy Against Pseudoperonospora cubensis
}

\author{
Anthony P. Keinath, Coastal Research and Education Center, Clemson University, Charleston, SC, 29414-5329
}

\begin{abstract}
Keinath, A. P. 2016. Utility of a Cucumber Plant Bioassay to Assess Fungicide Efficacy Against Pseudoperonospora cubensis. Plant Dis. 100:490-499.

Over a dozen fungicides are registered in the United States to manage cucurbit downy mildew caused by Pseudoperonospora cubensis. Efficacy varies greatly among them, due, in part, to reduced sensitivity to some fungicides in some pathogen populations. The objective of this study was to determine whether fungicide efficacy could be assessed using fungicide-treated cucumber (Cucumis sativus) exposed to natural inoculum for a brief period. Potted cucumber plants were treated with water or 1 of 13 fungicides registered to control cucurbit downy mildew. One day later, they were placed in a field among cucumber plants that had symptoms and signs of downy mildew. After a 48-h exposure to $P$. cubensis, potted plants were moved to a growth chamber held at day and night temperatures of 21 and $18^{\circ} \mathrm{C}$, respectively, and $50 \%$ relative humidity. Severity (leaf area with symptoms) of downy mildew was rated 5 and 7 days later. The assay was done eight times, twice each

in July and October 2013 and 2014. Year, season, trial, and interactions among these factors affected downy mildew development. Severity at 7 days on plants treated with mandipropamid, azoxystrobin, dimethomorph, cymoxanil, fluopicolide, and propamocarb was not significantly different from the water control treatment in eight, five, three, three, two, and two of eight bioassays, respectively. Severity on plants treated with cyazofamid, fluazinam, mancozeb + zoxamide, mancozeb, chlorothalonil, and ametoctradin + dimethomorph was less than on plants treated with water in all bioassays. These six fungicides should be effective when applied early in the season to prevent initial infections. Cyazofamid and mancozeb + zoxamide prevented an increase in severity between rating times. In conclusion, the assay consistently detected resistance to mandipropamid and azoxystrobin and demonstrated the efficacy of six other fungicides.
\end{abstract}

Cucurbit downy mildew, caused by Pseudoperonospora cubensis (Berk. \& M. A. Curtis) Rostovzev, is a serious disease on cucurbits throughout the eastern United States and Canada. Of all the cucurbits grown in this geographical area, pickling cucumber (Cucumis sativus L.) has been seriously affected, with dramatic reductions in yield and quality because of loss of photosynthetically active foliage (Adams and Quesada-Ocampo 2014; Colucci et al. 2007). Downy mildew also reduces yield and sugar content of muskmelon (Cucumis melo L.) and watermelon (Citrullus lanatus (Thunb.) Matsum. \& Nakai) (Keinath et al. 2007; Patterson 1989). Cucumber cultivars bred with resistance to downy mildew are susceptible to what appears to be a new race that was first found in the United States in 2004 (Holmes et al. 2015). No resistance is available in other cucurbits, although Cucurbita maxima Duch. ex Lam. has some tolerance (Keinath and DuBose 2000). Thus, fungicides are the main method to manage cucurbit downy mildew in conventional production systems.

$P$. cubensis is an obligate parasite. Because all of its hosts are frost sensitive, this oomycete survives outdoors in an active state only in areas below the 30th latitude, such as southern Florida and Texas and the Caribbean region (Holmes et al. 2015). The pathogen also could survive year-round on greenhouse-grown cucumber. In addition, $P$. cubensis has been reported to overwinter in China as oospores that formed in infected leaves (Zhang et al. 2012). Aerial movement of sporangia is the primary method of pathogen dispersal during the growing season; there is a pattern of north-to-south longdistance spread in the eastern United States (Ojiambo and Holmes 2011).

Corresponding author: A. P. Keinath; E-mail: tknth@ clemson.edu

This material is based upon work supported, in part, by National Institute of Food and Agriculture/United States Department of Agriculture under project numbers SC-1700446 and 2012-41530-19623. Technical Contribution Number 6360 of the Clemson University Experiment Station.

Accepted for publication 28 August 2015.

http://dx.doi.org/10.1094/PDIS-05-15-0499-RE

(C) 2016 The American Phytopathological Society
Although a large number of fungicide active ingredients are available against cucurbit downy mildew, selecting effective products can be challenging. Protectant (nonsystemic) fungicides such as chlorothalonil and mancozeb provide good protection if applications start before infection (Keinath et al. 2007). However, because these fungicides do not provide adequate protection from yield losses in pickling cucumber when they are applied season-long, growers must select other fungicides to apply after downy mildew appears (Adams et al. 2015; Colucci et al. 2007). Because P. cubensis has been found to be resistant to mefenoxam, quinone outside inhibitors (QoI), and mandipropamid, current information on fungicide efficacy is necessary (Colucci and Holmes 2007; Keinath et al. 2008; McGrath and Fox 2008; Olaya et al. 2009). For example, fluopicolide was the most effective fungicide in the eastern United States during 2000 and 2008 (Ojiambo et al. 2010). Recently, however, fluopicolide applied without being mixed with a protectant failed to control downy mildew in field trials in Georgia, North Carolina, and Michigan (Adams and Quesada-Ocampo 2014; Adams et al. 2014; Hausbeck and Linderman 2014; Langston and Sanders 2013). In the Czech Republic, isolates with reduced sensitivity to field rates of dimethomorph and cymoxanil were detected starting in 2005 (Pavelková et al. 2014).

Because $P$. cubensis is an obligate parasite, fungicide sensitivity assays must be done on a living host plant. A potted plant bioassay with summer squash (C. pepo L.) seedlings has been used to assess fungicide sensitivity in another obligate parasite, cucurbit powdery mildew (Podosphaera (sect. Sphaerotheca) xanthii; McGrath and Shishkoff 2001). Seedlings that had been treated with fungicides were placed in a field for 3 days next to plants already affected with powdery mildew to be exposed to natural inoculum. Sensitivity or resistance to fungicides was then determined by comparing ratings of powdery mildew on treated and nontreated plants.

A similar assay with a cucurbit cultivar highly susceptible to downy mildew may be useful to determine fungicide efficacy rapidly in Pseudoperonospora cubensis (Baysal-Gurel et al. 2015). An assay done early in the growing season, when cucurbit downy mildew appeared in an area, could be used to assess which fungicides lack efficacy against $P$. cubensis, so that other, more effective fungicides could be recommended and applied. For such an assay to be useful, results should be reproducible over time. The objective of this study 
was to evaluate a cucumber plant bioassay to assess the efficacy of fungicides currently registered to manage downy mildew on cucurbits.

\section{Materials and Methods}

Potted plants and fungicide applications. The bioassay was done eight times, twice each in July and October 2013 and 2014 (Table 1). Each bioassay was set up in a randomized, complete block design with four replications, one pot per replication. Two greenhouse-grown, 3-week-old cucumber 'Straight Eight' plants with at least three fully expanded leaves were transplanted into 10-by-10-cm square pots filled with Fafard 3B potting soil (Sun-Gro Horticulture). One day later, plants were sprayed just until run-off with 1 of 13 fungicides or water, which was 1 day prior to being placed in the field (Table 2). Fungicides were applied based on the labeled rate mixed in 467 liters water/ha, a typical volume of water used by cucurbit growers (Baysal-Gurel et al. 2015). Cymoxanil was applied at the rate equivalent to the rate of cymoxanil in Tanos $(0.14 \mathrm{~kg} / \mathrm{ha})$ instead of the labeled rate of $0.21 \mathrm{~kg} / \mathrm{ha}$. Mancozeb was applied at the rate equivalent to the rate of mancozeb in Gavel $(1.49 \mathrm{~kg} / \mathrm{ha})$ instead of the labeled rate of 1.68 to $2.52 \mathrm{~kg} / \mathrm{ha}$. Mandipropamid was included as a positive control for detecting fungicide resistance, because resistance to this active ingredient is widespread in the United States (Olaya et al. 2009). Fluazinam was tested in 2014 only, because it was not labeled on cucurbits until the end of 2013. Propamocarb was used at one-half rate in the first two bioassays in July 2013, based on a preliminary test in which it caused some phytotoxicity to muskmelon (Cucumis melo 'Athena' and 'Kermit'). It did not cause any phytotoxicity when applied to Straight Eight cucumber at the full label rate in bioassays three through eight.

In the field, potted cucumber plants were placed by replication (blocks) into four alleys between rows of cucumber plants that already had symptoms and signs of downy mildew due to infection by naturally occurring populations of uncharacterized isolates of P. cubensis. Plants remained in the field for $48 \mathrm{~h}$, starting at approximately 13:30. Plants were then moved to a growth chamber held at $21{ }^{\circ} \mathrm{C}$ during the lighted period from 6:00 to 18:00 and at $18^{\circ} \mathrm{C}$ during the dark period (Arauz et al. 2010). Relative humidity was set at $50 \%$ so that moisture did not condense on leaves. Two nontreated cucumber plants placed in the chamber remained symptomless in each bioassay, which indicated that there was no plantto-plant spread in the chamber.

Downy mildew severity was rated on a scale of 0 to $100 \%$ in $5 \%$ increments plus $1 \%$ for trace amounts of disease at 5 and 7 days after plants were placed into the chamber, or 7 and 9 days after the beginning of the exposure period (Neufeld and Ojiambo 2012). Severity was rated separately as the percent leaf area with chlorotic symptoms and with necrotic symptoms on two leaves per plant, generally leaves two and three. Ratings for chlorosis and necrosis were summed before analysis. Because the first true leaf on Straight Eight plants often failed to reach full size, it was not rated. In the first trial in October 2014, the second true leaf on some plants had cold damage (Table 1); therefore, in this bioassay, severities were rated on leaves three and four instead.

In the second trial in October 2013, some plants had symptoms of downy mildew that were atypical. Selected pots were placed individually into clear polyethylene bags 1 day after the 5-day rating and held overnight at ambient temperature $\left(23^{\circ} \mathrm{C}\right)$ to induce sporangia formation so that symptoms could be rated accurately at 7 days after exposure. In three bioassays done in 2014, plants were placed into black polyethylene bags 1 day after the 5-day rating and incubated in the growth chamber for 15 to $20 \mathrm{~h}$. This high-humidity incubation was used to induce sporangia formation, so that symptoms of senescence in the first July trial, wind injury in the second July trial, and chilling injury in the first October trial could be reliably distinguished from symptoms of downy mildew.

Experimental fields and environmental measurements. The bioassays were done at the Clemson University Coastal Research and Education Center in Charleston, SC. A preplant granular 15-0-15

Table 1. Environmental conditions during field exposure of cucumber plants to airborne sporangia of Pseudoperonospora cubensis for $48 \mathrm{~h}^{\mathrm{z}}$

\begin{tabular}{lccccrrr}
\hline Date & Trial & $\begin{array}{c}\text { Mean } \\
\text { temperature }\left({ }^{\circ} \mathbf{C}\right)^{\mathbf{z}}\end{array}$ & $\begin{array}{c}\text { Minimum } \\
\text { temperature }\left({ }^{\circ} \mathbf{C}\right)\end{array}$ & $\begin{array}{c}\text { Maximum } \\
\text { temperature }\left({ }^{\circ} \mathbf{C}\right)\end{array}$ & $\begin{array}{c}\text { Leaf } \\
\text { wetness }(\mathbf{h})\end{array}$ & $\begin{array}{c}\text { Rainfall } \\
(\mathbf{m m})\end{array}$ & $\begin{array}{c}\text { Photosynthetically active } \\
\text { radiation }\left(\boldsymbol{\mu M} / \mathbf{m}^{2} / \mathbf{s}\right)\end{array}$ \\
\hline 08-10 July 2013 & 1 & 26.4 & 21.4 & 31.1 & 13.5 & 0.25 & 95.1 \\
10-12 July 2013 & 2 & 26.2 & 22.8 & 31.1 & 5.0 & 2.29 & 200.0 \\
08-10 October 2013 & 1 & 18.4 & 14.6 & 24.9 & 9.0 & 0.51 & $1,905.2$ \\
12-14 October 2013 & 2 & 21.1 & 16.8 & 27.3 & 13.5 & 0.00 & 771.2 \\
04-06 July 2014 & 1 & 25.4 & 20.1 & 31.2 & 31.5 & 0.00 & $7,192.1$ \\
08-10 July 2014 & 2 & 27.2 & 21.8 & 33.3 & 10.0 & 0.00 & $9,750.0$ \\
21-23 October 2014 & 1 & 15.7 & 6.3 & 25.6 & 23.0 & 0.00 & $5,706.2$ \\
28-30 October 2014 & 2 & 19.7 & 13.1 & 27.7 & 27.0 & 0.00 & $11,530.7$ \\
\hline
\end{tabular}

${ }^{\mathrm{z}}$ Minimum and maximum temperatures during the 48-h exposure period based on measurements taken every minute. Leaf wetness, rainfall, and photosynthetically active radiation are the cumulative value during the 48-h exposure period.

Table 2. Fungicides applied to potted cucumber plants 1 day before 48-h exposure to natural inoculum of Pseudoperonospora cubensis

\begin{tabular}{|c|c|c|c|c|c|}
\hline Fungicide & $\begin{array}{l}\text { Trade name and } \\
\text { formulation }\end{array}$ & $\begin{array}{c}\text { FRAC } \\
\text { code }\end{array}$ & $\begin{array}{c}\text { Labeled rate } \\
(\mathrm{kg} / \mathrm{ha})^{\mathrm{x}}\end{array}$ & $\begin{array}{c}\text { Amount } \\
\text { product } / 200 \mathrm{ml}\end{array}$ & $\begin{array}{c}\text { Concentration } \\
(\mathrm{mg} / \text { /liter })^{\mathrm{x}}\end{array}$ \\
\hline Mandipropamid 23.3\% & Revus 2.08SC & 40 & 0.15 & $0.25 \mathrm{ml}$ & 312 \\
\hline Azoxystrobin $22.9 \%$ & Quadris 2.08F & 11 & 0.28 & $0.48 \mathrm{ml}$ & 600 \\
\hline Dimethomorph $43.5 \%$ & Forum 4.16SC & 40 & 0.23 & $0.20 \mathrm{ml}$ & 492 \\
\hline Fluopicolide $39.5 \%$ & Presidio 4SC & 43 & 0.14 & $0.12 \mathrm{ml}$ & 300 \\
\hline Propamocarb $66.5 \%$ & Previcur Flex 6SL & 28 & 1.01 & $0.60 \mathrm{ml}$ & 2160 \\
\hline Cymoxanil $25 \%+$ famoxadone $25 \%$ & Tanos 50DF & $27+11$ & $0.14+0.14$ & $0.24 \mathrm{~g}$ & $300+300$ \\
\hline Cymoxanil $60 \%$ & Curzate 60DF & 27 & $0.14^{\mathrm{y}}$ & $0.10 \mathrm{~g}$ & 300 \\
\hline Ametoctradin $26.9 \%$ + dimethomorph $20.2 \%$ & Zampro 525SC & $45+40$ & $0.23+0.31$ & $0.44 \mathrm{ml}$ & $493+656$ \\
\hline Chlorothalonil $54 \%$ & Bravo Weather Stik 6F & M5 & 1.68 & $1.00 \mathrm{ml}$ & 3599 \\
\hline Mancozeb $66.7 \%$ + zoxamide $8.3 \%$ & Gavel 75DF & $\mathrm{M} 3+22$ & $1.49+0.19$ & $0.96 \mathrm{~g}$ & $408+3191$ \\
\hline Mancozeb $75 \%$ & Manzate ProStik 75DG & M3 & $1.49^{\mathrm{z}}$ & $0.85 \mathrm{~g}$ & 3185 \\
\hline Cyazofamid $23.3 \%$ & Ranman 400SC & 21 & 0.080 & $0.09 \mathrm{ml}$ & 170 \\
\hline Fluazinam $40 \%$ & Omega $500 \mathrm{~F}$ & 29 & 0.88 & $0.75 \mathrm{ml}$ & 1876 \\
\hline
\end{tabular}

${ }^{x}$ Fungicides were applied based on the labeled rate mixed in water at 467 liters/ha.

y Cymoxanil was applied at the rate equivalent to the rate of cymoxanil in Tanos instead of the labeled rate of $0.21 \mathrm{~kg} / \mathrm{ha}$.

${ }^{\mathrm{z}}$ Mancozeb was applied at the rate equivalent to the rate of mancozeb in Gavel instead of the labeled rates of 1.68 to $2.52 \mathrm{~kg} / \mathrm{ha}$. 
$\mathrm{N}-\mathrm{P}-\mathrm{K}$ fertilizer was applied to each field at $560 \mathrm{~kg} / \mathrm{ha}$. Liquid $8-0-8$ fertilizer was applied throughout the season through the drip irrigation system; the volume of fertilizer was adjusted weekly according to plant development. For all experiments, 0.91-m-wide raised beds were formed on $1.8-\mathrm{m}$ centers and covered with white-on-black polyethylene mulch. To provide a source of natural inoculum for potted cucumber plants, cucumber 'Poinsett 76' was seeded on 1 May and 14 August 2013 and 28 April and 5 September 2014. Cucumber was seeded into every other row in 10 rows of 13 plants per row spaced $0.61 \mathrm{~m}$ apart within rows. Field cucumber plants became diseased with cucurbit downy mildew due to infection by naturally occurring inoculum. Spring plantings were sprayed with paraquat and mowed several weeks before fall plantings were seeded, so that inoculum did not survive locally between seasons.

Standard pesticides used in cucurbit production were applied to prevent or manage weeds, insects, mites, anthracnose, and powdery mildew (Kemble et al. 2015). Gummy stem blight was controlled by applications of chlorothalonil (Bravo Weather Stik 6F) at $1.68 \mathrm{~kg} / \mathrm{ha}$ on 5 and 26 June 2013. Mefenoxam (Ridomil Gold SL) was applied through the drip irrigation at the rate of $1.12 \mathrm{~kg} / \mathrm{ha}$ on 27 August 2014 to prevent Pythium damping-off. Copper hydroxide (Kocide 3000; $0.26 \mathrm{~kg} / \mathrm{ha}$ ) was applied on 7 and 15 October 2014 to control a Pseudomonas leaf spot on the older leaves.

Air temperature and precipitation were measured and recorded with a Watchdog 2700 Weather Station (Spectrum Technologies). Temperature was measured every minute. Photosynthetically active radiation between 400 and $700 \mathrm{~nm}$ was measured with a LightScout Quantum Light Sensor, model 3668I, and leaf wetness was measured with a Leaf Wetness Sensor, model 3600 (Spectrum Technologies). Any degree of leaf wetness $>0$ (range 0.1 to 15 ) was included when leaf wetness duration was calculated.

Data analysis. Five measurements of disease were analyzed in this study. The three primary variables were disease incidence at 7 days and disease severity rated at 5 and 7 days after exposure to $P$. cubensis. Incidence at 5 days was not analyzed. For disease severity, ratings for chlorosis and necrosis were summed. Two additional variables were derived from severity ratings: severity relative to the water control treatment in the same replication and the difference between severity ratings (usually an increase). Severity relative to the water control treatment was calculated by dividing the percent severity rating for each fungicide by the percent severity for the water control treatment in the same replication. The difference in severity was calculated by subtracting the percent disease severity at 5 days from the percent disease severity at 7 days. Because severity was rated on a scale with $5 \%$ increments, if the difference in severity ratings between 5 and 7 days after exposure was negative and the absolute value was $<5.0 \%$, then the difference was replaced by 0 before analysis. If the absolute value of the difference was $>5.0 \%$, then the difference was considered a missing value. This happened only once, for fluazinam in the first trial in October 2014. Percent control (i.e., 1 - relative severity) was not included because negative values obtained for one or more fungicides in some bioassays could not be analyzed.

Disease incidence was calculated based on the number of diseased plants per experimental unit $(0,1$, or 2$)$ and on the number of diseased leaves per experimental unit (i.e., 0 to 4 of 4 leaves rated). Both incidence variables were examined in preliminary analyses. When there was a difference between the variables, incidence calculated based on leaves had smaller residuals and -2 res log likelihood values in SAS PROC MIXED (a measure of how well the model fit the data) than incidence based on plants. In addition, incidence based on plants did not vary among treatments for two of the eight bioassays (July 2013 trial 2 and July 2014 trial 1), when disease incidence was 69 to $100 \%$ in each bioassay (data not shown). Thus, incidence based on the number of leaves with symptoms was presented.

Disease variables were analyzed with a mixed-model maximumlikelihood analysis (SAS PROC MIXED, version 9.3; SAS, Inc.) with a split-split-split-unit model, with year (whole unit), season (subunit), trial (subsubunit), treatment (subsub-subunit), and all interactions as fixed effects and replication within year-season-trial as a random effect. Incidence and severity values were transformed before analysis by calculating the arcsine of the square root. Residuals from analyses of variance were checked for nonnormality and inequality of variance with PROC UNIVARIATE. Back-transformed least-squares means are shown in the tables. Treatment means were compared with Fisher's protected least significant difference. Incidence and severity at 7 days after exposure for the water control treatment in all eight bioassays were examined in separate analyses. Severity ratings at 5 and 7 days after exposure were compared using the repeated option of PROC MIXED. All $F$ values and $t$ values were evaluated at $P \leq 0.01$.

To compare the usefulness of the five disease measurements (severity at 5 and 7 days, incidence at 7 days, relative disease severity at 7 days, and the increase in severity between 5 and 7 days), fungicide means were examined based on two criteria: not significantly different from the water control treatment and not significantly different from the fungicide with the least amount of disease. When fungicide means met both criteria simultaneously, the first criterion took precedence. The number of times that fungicide treatments met each criterion was tabulated. The totals for the 13 fungicides and the five disease measurements were analyzed with SAS PROC CATMOD. Proportions (response for a fungicide divided by the number of bioassays that included the fungicide) were transformed by calculating the logit before analysis. Fungicides were compared with contrasts of maximum-likelihood estimates evaluated with $\chi^{2}$ tests evaluated at $P \leq 0.01$.

\section{Results}

Fungicide efficacy ratings. Severity of downy mildew on a susceptible cucumber cultivar not treated with a fungicide (i.e., the water control treatment) varied significantly by year, season, and trial (three-way interaction, $P \leq 0.01$ ). The most severe downy mildew, which affected $72 \%$ of the leaf area, developed in trial 2 in July 2013, when $2.3 \mathrm{~mm}$ of rain fell during the exposure period (Table 1). The next most severe downy mildew was observed in trial 2 in October 2014, when fog occurred on the first morning (29 October) that the plants were in the field. The least severe downy mildew, $7 \%$, developed in trial 2 in October 2013. Severity of downy mildew in the water control treatment did not differ between the two trials in July 2013 but differed between trials in July 2014 and October 2013 and 2014.

Repeated-measures analysis of severity ratings revealed that, in seven bioassays (all four in 2013, the second in July 2014, and both in October 2014), the differences between two or more treatments changed significantly between 5 and 7 days after exposure to natural inoculum of $P$. cubensis (time-treatment interaction, $P \leq 0.02$ ). For example, in the first bioassay in October 2014, severity on plants treated with dimethomorph and cymoxanil + famoxadone was not significantly less than the water control treatment at 5 days but was significantly less at 7 days (Tables 3 and 4). In the second bioassay in July 2014, treatments did not differ at 5 days but differed at 7 days. Thus, severity data collected at 5 and 7 days after exposure were analyzed separately.

Incidence of downy mildew, measured as the proportion of four leaves (two per plant) with symptoms 7 days after the exposure period, was $\geq 75 \%$ in the water control treatment in all eight bioassays. This treatment did not differ significantly among bioassays. However, there was a significant year-season-trial-fungicide interaction $(P<0.0001)$; therefore, data for each bioassay were analyzed separately. Incidence reached $100 \%$ in at least one treatment in six bioassays, and incidence of $0 \%$ was observed for one or more treatments in four bioassays (Table 5). Incidence did not differ between the water control treatment and any fungicide treatments in the first trial done in July 2014. In the other seven bioassays, cyazofamid reduced incidence compared with the water control treatment (Table 5). The next most effective fungicides at reducing incidence were chlorothalonil, mancozeb + zoxamide, mancozeb, and fluazinam, which did so half of the time. In contrast, incidence on plants treated with mandipropamid, dimethomorph, and azoxystrobin was not 
significantly different from the water control treatment in eight, eight, and seven of eight bioassays, respectively, and cymoxanil was not significantly different from the water control treatment in five of six bioassays. In addition, incidence on plants treated with fluopicolide, cymoxanil + famoxadone, and ametoctradin + dimethomorph was not significantly different from the water control treatment in six of eight bioassays (Table 5). Overall, in six of the eight bioassays, $\leq 50 \%$ of the fungicides reduced incidence compared with the water control.

Across all eight bioassays, the greatest severity of downy mildew (chlorosis and necrosis combined) rated 5 days after exposure to P. cubensis was in October 2014, with $46 \%$ leaf area diseased on plants treated with water. In the second bioassay done in July 2014, severity rated at 5 days was very low, 0 to $3 \%$; there were no significant differences among treatments at 5 days but severity differed among treatments at 7 days (Tables 3 and 4). In all, 5 to 10 fungicides reduced severity of downy mildew in the other seven bioassays. In general, most fungicides that reduced downy mildew severity at 5 days also reduced severity at 7 days (Tables 3 and 4). Mandipropamid and azoxystrobin were not significantly different from the water control treatment in seven and five of the eight bioassays, respectively. Chlorothalonil, cyazofamid, and mancozeb + zoxamide grouped with the most effective fungicides in seven, seven, and six of eight bioassays, respectively, while mancozeb grouped with the most effective fungicides five of six times (Table 3). Fluazinam was among the most effective fungicides in three of four bioassays done in 2014.

The greatest severity of downy mildew (60\%) rated 7 days after the exposure period on plants treated with a fungicide was recorded in the first bioassay done in July 2013 on plants treated with fluopicolide (Table 4). Severity on plants treated with mandipropamid, azoxystrobin, dimethomorph, cymoxanil, cymoxanil + famoxadone, fluopicolide, and propamocarb was not significantly different from the water control treatment in eight, five, three, three, three, two, and two bioassays, respectively. Cucumber plants treated with cyazofamid, fluazinam, mancozeb + zoxamide, mancozeb, chlorothalonil, and ametoctradin + dimethomorph had less severe disease than the water control treatment in all bioassays. Cyazofamid and mancozeb were grouped with the most effective fungicides in eight of eight and six of six bioassays, respectively; mancozeb + zoxamide, chlorothalonil, and ametoctradin + dimethomorph grouped with the most effective fungicides seven, six, and five times, respectively (Table 4). Fluazinam was among the most effective fungicides in three of four bioassays in 2014.

Table 3. Severity (\%) of downy mildew on cucumber plants 5 days after exposure to natural inoculum of Pseudoperonospora cubensis in July and October 2013 and $2014^{\mathrm{y}}$

\begin{tabular}{|c|c|c|c|c|c|c|c|c|}
\hline \multirow[b]{2}{*}{ Fungicide $^{\mathrm{z}}$} & \multicolumn{2}{|c|}{ July 2013} & \multicolumn{2}{|c|}{ October 2013} & \multicolumn{2}{|c|}{ July 2014} & \multicolumn{2}{|c|}{ October 2014} \\
\hline & Trial 1 & $\overline{\text { Trial } 2}$ & Trial 1 & $\overline{\text { Trial } 2}$ & Trial 1 & Trial 2 & Trial 1 & Trial 2 \\
\hline None; water control & $8.8 \mathrm{a}$ & $28.3 \mathrm{a}$ & $12.6 \mathrm{a}$ & $4.7 \mathrm{a}$ & $10.5 \mathrm{a}$ & $0.6 \mathrm{a}$ & $6.7 \mathrm{ab}$ & $45.6 \mathrm{a}$ \\
\hline Mandipropamid $23.3 \%$ & $6.3 \mathrm{ab}$ & $25.1 \mathrm{a}$ & $6.6 \mathrm{ab}$ & $3.0 \mathrm{ab}$ & $7.5 \mathrm{a}$ & $0.2 \mathrm{a}$ & $16.0 \mathrm{a}$ & $34.5 \mathrm{ab}$ \\
\hline Azoxystrobin $22.9 \%$ & $9.6 \mathrm{a}$ & $15.8 \mathrm{ab}$ & $1.6 \mathrm{bcd}$ & 0.7 cde & $9.2 \mathrm{a}$ & $2.7 \mathrm{a}$ & $7.0 \mathrm{ab}$ & $35.1 \mathrm{ab}$ \\
\hline Dimethomorph $43.5 \%$ & $5.5 \mathrm{ab}$ & $6.2 \mathrm{bc}$ & $1.8 \mathrm{bcd}$ & $1.4 \mathrm{bcd}$ & $0.9 \mathrm{~cd}$ & $0.8 \mathrm{a}$ & $4.8 \mathrm{bc}$ & $43.8 \mathrm{a}$ \\
\hline Fluopicolide $39.5 \%$ & $6.5 \mathrm{ab}$ & $2.3 \mathrm{cde}$ & $0.8 \mathrm{~cd}$ & $2.0 \mathrm{abc}$ & $0.3 \mathrm{~cd}$ & $0.4 \mathrm{a}$ & $0.0 \mathrm{~d}$ & $0.1 \mathrm{f}$ \\
\hline Propamocarb $66.5 \%$ & $2.4 \mathrm{abc}$ & $0.1 \mathrm{de}$ & $0.0 \mathrm{~d}$ & 0.3 cde & $5.8 \mathrm{ab}$ & $0.4 \mathrm{a}$ & $0.0 \mathrm{~d}$ & $15.6 \mathrm{bcd}$ \\
\hline Cymoxanil $25 \%+$ famoxadone $25 \%$ & $0.0 \mathrm{c}$ & $4.3 \mathrm{c}$ & $0.2 \mathrm{~d}$ & $0.2 \mathrm{de}$ & $5.1 \mathrm{ab}$ & $2.5 \mathrm{a}$ & $1.9 \mathrm{bcd}$ & $33.6 \mathrm{ab}$ \\
\hline Cymoxanil $60 \%$ & n.d. & n.d. & $0.2 \mathrm{~d}$ & $0.0 \mathrm{e}$ & $3.6 \mathrm{abc}$ & $1.4 \mathrm{a}$ & $0.5 \mathrm{~cd}$ & $25.9 \mathrm{abc}$ \\
\hline Ametoctradin $26.9 \%+$ dimethomorph $20.2 \%$ & $0.6 \mathrm{bc}$ & $3.1 \mathrm{~cd}$ & $4.7 \mathrm{abc}$ & $0.0 \mathrm{e}$ & $0.3 \mathrm{~cd}$ & $1.8 \mathrm{a}$ & $0.5 \mathrm{~cd}$ & $3.5 \mathrm{def}$ \\
\hline Chlorothalonil $54 \%$ & $0.6 \mathrm{bc}$ & $0.02 \mathrm{de}$ & $0.5 \mathrm{~cd}$ & $0.0 \mathrm{e}$ & $1.0 \mathrm{~cd}$ & $0.0 \mathrm{a}$ & $0.1 \mathrm{~d}$ & $3.7 \mathrm{def}$ \\
\hline Mancozeb $66.7 \%$ + zoxamide $8.3 \%$ & $0.0 \mathrm{c}$ & $0.1 \mathrm{de}$ & $0.6 \mathrm{~cd}$ & $0.0 \mathrm{e}$ & $0.1 \mathrm{~cd}$ & $1.6 \mathrm{a}$ & $0.1 \mathrm{~d}$ & $8.8 \mathrm{cde}$ \\
\hline Mancozeb 75\% & n.d. & n.d. & $0.6 \mathrm{~cd}$ & $0.0 \mathrm{e}$ & $0.6 \mathrm{~cd}$ & $0.4 \mathrm{a}$ & $0.1 \mathrm{~d}$ & 1.9 ef \\
\hline Cyazofamid $23.3 \%$ & $0.0 \mathrm{c}$ & $0.00 \mathrm{e}$ & $0.2 \mathrm{~d}$ & $0.0 \mathrm{e}$ & $0.0 \mathrm{~d}$ & $0.0 \mathrm{a}$ & $0.1 \mathrm{~d}$ & $0.0 \mathrm{f}$ \\
\hline Fluazinam $40 \%$ & n.d. & n.d. & $\ldots$ & $\ldots$ & $1.3 \mathrm{~cd}$ & $0.0 \mathrm{a}$ & $0.5 \mathrm{~cd}$ & $0.1 \mathrm{f}$ \\
\hline
\end{tabular}

${ }^{\mathrm{y}}$ Means shown are least-squares means back-transformed from arcsine-square roots used in the analysis of variance. Means within a column with the same letter are not significantly different, Fisher's protected least significant difference, $P \leq 0.01$; n.d. $=$ not done.

${ }^{\mathrm{z}}$ Fungicides were applied at the rates shown in Table 2, 1 day before plants were exposed for $48 \mathrm{~h}$ to natural inoculum in the field.

Table 4. Severity (\%) of downy mildew on cucumber plants 7 days after exposure to natural inoculum of Pseudoperonospora cubensis in July and October 2013 and $2014^{\mathrm{y}}$

\begin{tabular}{|c|c|c|c|c|c|c|c|c|}
\hline \multirow[b]{2}{*}{ Fungicide $^{\mathrm{z}}$} & \multicolumn{2}{|c|}{ July 2013} & \multicolumn{2}{|c|}{ October 2013} & \multicolumn{2}{|c|}{ July 2014} & \multicolumn{2}{|c|}{ October 2014} \\
\hline & Trial 1 & Trial 2 & Trial 1 & Trial 2 & Trial 1 & Trial 2 & Trial 1 & Trial 2 \\
\hline None; water control & $51.4 \mathrm{ab}$ & $72.1 \mathrm{a}$ & $29.5 \mathrm{a}$ & $7.1 \mathrm{a}$ & $39.3 \mathrm{ab}$ & $11.8 \mathrm{a}$ & $27.7 \mathrm{a}$ & $55.6 \mathrm{a}$ \\
\hline Mandipropamid $23.3 \%$ & $41.8 \mathrm{ab}$ & $55.9 \mathrm{ab}$ & $30.2 \mathrm{a}$ & $4.8 \mathrm{ab}$ & $45.2 \mathrm{a}$ & $8.0 \mathrm{ab}$ & $25.6 \mathrm{a}$ & $47.2 \mathrm{a}$ \\
\hline Azoxystrobin $22.9 \%$ & $52.5 \mathrm{ab}$ & $40.8 \mathrm{bc}$ & $8.8 \mathrm{bc}$ & $0.7 \mathrm{~cd}$ & $45.6 \mathrm{a}$ & $12.8 \mathrm{a}$ & $22.5 \mathrm{ab}$ & $47.0 \mathrm{a}$ \\
\hline Dimethomorph $43.5 \%$ & $34.3 \mathrm{bc}$ & $28.1 \mathrm{bcd}$ & $5.6 \mathrm{bcd}$ & $2.6 \mathrm{bc}$ & $20.6 \mathrm{bc}$ & 2.2 bcde & $13.8 \mathrm{~b}$ & $53.7 \mathrm{a}$ \\
\hline Fluopicolide $39.5 \%$ & $59.8 \mathrm{a}$ & 16.2 cde & $6.4 \mathrm{bc}$ & $1.5 \mathrm{c}$ & $20.2 \mathrm{bc}$ & $1.0 \mathrm{de}$ & $0.0 \mathrm{~d}$ & $0.5 \mathrm{de}$ \\
\hline Propamocarb $66.5 \%$ & $20.4 \mathrm{c}$ & $3.9 \mathrm{e}$ & $0.1 \mathrm{e}$ & $0.0 \mathrm{de}$ & $21.3 \mathrm{bc}$ & $6.3 \mathrm{abc}$ & $0.0 \mathrm{~d}$ & $16.8 \mathrm{bc}$ \\
\hline Cymoxanil $25 \%+$ famoxadone $25 \%$ & $3.4 \mathrm{de}$ & $41.4 \mathrm{bc}$ & 1.9 cde & $0.0 \mathrm{de}$ & $23.1 \mathrm{bc}$ & $7.7 \mathrm{ab}$ & $3.4 \mathrm{c}$ & $52.5 \mathrm{a}$ \\
\hline Cymoxanil $60 \%$ & n.d. & n.d. & $7.1 \mathrm{bc}$ & $0.1 \mathrm{de}$ & $19.6 \mathrm{bc}$ & 4.7 abcd & $2.1 \mathrm{c}$ & $38.1 \mathrm{ab}$ \\
\hline Ametoctradin $26.9 \%$ + dimethomorph $20.2 \%$ & 3.9 de & $11.2 \mathrm{de}$ & $11.6 \mathrm{~b}$ & $0.1 \mathrm{de}$ & 14.2 cde & 1.2 cde & $4.6 \mathrm{c}$ & $5.3 \mathrm{cde}$ \\
\hline Chlorothalonil 54\% & $4.3 \mathrm{~d}$ & $2.3 \mathrm{e}$ & 2.1 cde & $0.0 \mathrm{e}$ & 7.7 cdef & $0.6 \mathrm{de}$ & $2.3 \mathrm{c}$ & $5.5 \mathrm{cde}$ \\
\hline Mancozeb $66.7 \%$ + zoxamide $8.3 \%$ & $0.0 \mathrm{e}$ & $3.4 \mathrm{e}$ & 3.4 bcde & $0.0 \mathrm{e}$ & 3.9 ef & $0.8 \mathrm{de}$ & $0.0 \mathrm{~d}$ & $8.7 \mathrm{~cd}$ \\
\hline Mancozeb $75 \%$ & n.d. & n.d. & 2.2 bcde & $0.0 \mathrm{e}$ & 4.9 ef & $0.2 \mathrm{e}$ & $0.5 \mathrm{~cd}$ & $3.2 \mathrm{cde}$ \\
\hline Cyazofamid $23.3 \%$ & $0.0 \mathrm{e}$ & $1.8 \mathrm{e}$ & $0.2 \mathrm{de}$ & $0.0 \mathrm{e}$ & $5.7 \mathrm{def}$ & $0.0 \mathrm{e}$ & $0.6 \mathrm{~cd}$ & $0.1 \mathrm{e}$ \\
\hline Fluazinam $40 \%$ & n.d. & n.d. & n.d. & n.d. & $1.4 \mathrm{f}$ & $0.1 \mathrm{e}$ & $5.1 \mathrm{c}$ & $0.6 \mathrm{de}$ \\
\hline
\end{tabular}

y Means shown are least-squares means back-transformed from arcsine-square roots used in the analysis of variance. Means within a column with the same letter are not significantly different, Fisher's protected least significant difference, $P \leq 0.01 ;$ n.d. $=$ not done.

${ }^{\mathrm{z}}$ Fungicides were applied at the rates shown in Table 2, 1 day before plants were exposed for $48 \mathrm{~h}$ to natural inoculum in the field. 
Results of the analysis of relative severity calculated 7 days after the exposure period were very similar to the results of disease severity ratings 7 days after exposure, except for dimethomorph and ametoctradin + dimethomorph (Table 6). In the first bioassay in October 2014 , relative severity on plants treated with dimethomorph was not significantly different from the water control treatment, even though severity with dimethomorph was numerically less. In the two bioassays in July 2013, relative severity for ametoctradin + dimethomorph was numerically greater than relative severity for cyazofamid but severity values did not differ between these treatments. Based on analysis of variance of the 96 fungicide-bioassay combinations in this study (Table 6), 25 of the 26 relative severity values $>50 \%$ were not significantly different from the water control treatment at $P \leq 0.01$. Moreover, of the 70 relative severity values $\leq 50 \%$, only 2 were not significantly different from the water control treatment (two values for cymoxanil in the two bioassays in July 2014; Table 6).

The fifth measure of fungicide efficacy was the increase in disease severity between 5 and 7 days after exposure. The greatest increase was observed in July 2013 in the first bioassay on plants treated with fluopicolide, when the difference in the severity ratings was $52 \%$ (Table 7). The next greatest difference, $42 \%$, was for the water control treatment in the second bioassay in July 2013. In the remaining six bioassays, the increase between the two ratings was $\leq 23 \%$. There was a significant year-season-trial-fungicide interaction $(P<0.0001)$; therefore, data for each bioassay were analyzed separately. One reason for the four-way interaction was that, in the second bioassay in October 2013, severity increased only in the water control and mandipropamid treatments; whereas, in the other bioassays, severity also increased in other fungicide treatments (Table 7). As with the other measurements of fungicide efficacy, the increase in severity on plants treated with mandipropamid, azoxystrobin, and dimethomorph was not significantly different from the increase on plants treated with water in seven, five, and five of the eight bioassays, respectively. Cyazofamid and mancozeb + zoxamide were grouped with the most effective fungicides in all eight bioassays, and mancozeb grouped with the most effective fungicides in five of six bioassays (Table 7). Fluazinam was among the most effective fungicides in three of four bioassays in 2014. One of the notable differences from other variables was that chlorothalonil and ametoctradin + dimethomorph did not differ from the water control treatment in two bioassays each (Table 7).

Fungicide efficacy patterns. When the number of times fungicide treatments in the eight bioassays did not differ from the water control

Table 5. Incidence (\%) of downy mildew on cucumber plants 7 days after exposure to natural inoculum of Pseudoperonospora cubensis in July and October 2013 and $2014^{y}$

\begin{tabular}{|c|c|c|c|c|c|c|c|c|}
\hline \multirow[b]{2}{*}{ Fungicide $^{\mathrm{z}}$} & \multicolumn{2}{|c|}{ July 2013} & \multicolumn{2}{|c|}{ October 2013} & \multicolumn{2}{|c|}{ July 2014} & \multicolumn{2}{|c|}{ October 2014} \\
\hline & Trial 1 & Trial 2 & Trial 1 & Trial 2 & Trial 1 & Trial 2 & Trial 1 & Trial 2 \\
\hline None; water control & $100.0 \mathrm{a}$ & $100.0 \mathrm{a}$ & $100.0 \mathrm{a}$ & $80.4 \mathrm{ab}$ & $85.4 \mathrm{ab}$ & $75.0 \mathrm{abc}$ & $76.9 \mathrm{ab}$ & $100.0 \mathrm{a}$ \\
\hline Mandipropamid $23.3 \%$ & $100.0 \mathrm{a}$ & $100.0 \mathrm{a}$ & $100.0 \mathrm{a}$ & $92.2 \mathrm{a}$ & $100.0 \mathrm{a}$ & $85.4 \mathrm{ab}$ & $69.1 \mathrm{ab}$ & $100.0 \mathrm{a}$ \\
\hline Azoxystrobin $22.9 \%$ & $98.3 \mathrm{a}$ & $100.0 \mathrm{a}$ & $89.7 \mathrm{ab}$ & $30.9 \mathrm{~cd}$ & $100.0 \mathrm{a}$ & $100.0 \mathrm{a}$ & $80.4 \mathrm{ab}$ & $100.0 \mathrm{a}$ \\
\hline Dimethomorph $43.5 \%$ & $100.0 \mathrm{a}$ & $100.0 \mathrm{a}$ & $85.4 \mathrm{ab}$ & $50.0 \mathrm{abc}$ & $98.3 \mathrm{ab}$ & $37.1 \mathrm{bcd}$ & $98.3 \mathrm{a}$ & $100.0 \mathrm{a}$ \\
\hline Fluopicolide $39.5 \%$ & $100.0 \mathrm{a}$ & $100.0 \mathrm{a}$ & $93.3 \mathrm{ab}$ & $50.0 \mathrm{abc}$ & $100.0 \mathrm{a}$ & $50.0 \mathrm{bcd}$ & $0.0 \mathrm{e}$ & $19.6 \mathrm{de}$ \\
\hline Propamocarb $66.5 \%$ & $96.2 \mathrm{a}$ & $85.4 \mathrm{ab}$ & $3.8 \mathrm{e}$ & $1.7 \mathrm{~d}$ & $100.0 \mathrm{a}$ & $85.4 \mathrm{ab}$ & $0.0 \mathrm{e}$ & $89.7 \mathrm{ab}$ \\
\hline Cymoxanil $25 \%+$ famoxadone $25 \%$ & $50.0 \mathrm{~b}$ & $100.0 \mathrm{a}$ & 69.1 abcd & $1.7 \mathrm{~d}$ & $98.3 \mathrm{ab}$ & $62.9 \mathrm{abc}$ & $54.3 \mathrm{~b}$ & $100.0 \mathrm{a}$ \\
\hline Cymoxanil $60 \%$ & n.d. & n.d. & $80.4 \mathrm{abc}$ & $6.7 \mathrm{~cd}$ & $100.0 \mathrm{a}$ & $81.6 \mathrm{abc}$ & $39.2 \mathrm{bcd}$ & $100.0 \mathrm{a}$ \\
\hline Ametoctradin $26.9 \%+$ dimethomorph $20.2 \%$ & $62.9 \mathrm{~b}$ & $100.0 \mathrm{a}$ & $100.0 \mathrm{a}$ & $1.7 \mathrm{~d}$ & $100.0 \mathrm{a}$ & $43.5 \mathrm{bcd}$ & $47.8 \mathrm{bc}$ & $75.0 \mathrm{abc}$ \\
\hline Chlorothalonil $54 \%$ & $56.5 \mathrm{~b}$ & $69.1 \mathrm{~b}$ & $25.0 \mathrm{de}$ & $0.0 \mathrm{~d}$ & $98.3 \mathrm{ab}$ & $25.0 \mathrm{bcd}$ & $41.3 \mathrm{bcd}$ & $43.5 \mathrm{bcd}$ \\
\hline Mancozeb $66.7 \%$ + zoxamide $8.3 \%$ & $0.0 \mathrm{c}$ & $56.5 \mathrm{~b}$ & $56.5 \mathrm{bcd}$ & $0.0 \mathrm{~d}$ & $85.4 \mathrm{ab}$ & $14.6 \mathrm{~cd}$ & $0.0 \mathrm{e}$ & $80.4 \mathrm{ab}$ \\
\hline Mancozeb $75 \%$ & n.d. & n.d. & 50.0 bcde & $0.0 \mathrm{~d}$ & $89.7 \mathrm{ab}$ & $11.3 \mathrm{~cd}$ & $7.8 \mathrm{cde}$ & $69.1 \mathrm{bcd}$ \\
\hline Cyazofamid $23.3 \%$ & $0.0 \mathrm{c}$ & $50.0 \mathrm{~b}$ & $19.6 \mathrm{de}$ & $0.0 \mathrm{~d}$ & $56.5 \mathrm{~b}$ & $1.7 \mathrm{~d}$ & $3.8 \mathrm{de}$ & $1.7 \mathrm{e}$ \\
\hline Fluazinam $40 \%$ & n.d. & n.d. & n.d. & n.d. & $62.9 \mathrm{~b}$ & $0.0 \mathrm{~d}$ & $67.1 \mathrm{ab}$ & $25.0 \mathrm{cde}$ \\
\hline
\end{tabular}

${ }^{\mathrm{y}}$ Means shown are least-squares means back-transformed from arcsine-square roots used in the analysis of variance. Means within a column with the same letter are not significantly different, Fisher's protected least significant difference, $P \leq 0.01$; n.d. $=$ not done.

${ }^{\mathrm{z}}$ Fungicides were applied at the rates shown in Table 2, 1 day before plants were exposed for $48 \mathrm{~h}$ to natural inoculum in the field.

Table 6. Severity (\%) of downy mildew relative to the water control treatment on cucumber plants 7 days after exposure to natural inoculum of Pseudoperonospora cubensis in July and October 2013 and $2014^{\mathrm{Y}}$

\begin{tabular}{|c|c|c|c|c|c|c|c|c|}
\hline \multirow[b]{2}{*}{ Fungicide $^{\mathrm{z}}$} & \multicolumn{2}{|c|}{ July 2013} & \multicolumn{2}{|c|}{ October 2013} & \multicolumn{2}{|c|}{ July 2014} & \multicolumn{2}{|c|}{ October 2014} \\
\hline & Trial 1 & Trial 2 & Trial 1 & Trial 2 & Trial 1 & Trial 2 & Trial 1 & Trial 2 \\
\hline None; water control & $100.0 \mathrm{ab}$ & $100.0 \mathrm{a}$ & $100.0 \mathrm{a}$ & $100.0 \mathrm{a}$ & $100.0 \mathrm{abc}$ & $100.0 \mathrm{a}$ & $100.0 \mathrm{a}$ & $100.0 \mathrm{a}$ \\
\hline Mandipropamid $23.3 \%$ & $81.5 \mathrm{ab}$ & $77.2 \mathrm{ab}$ & $106.8 \mathrm{a}$ & $72.0 \mathrm{ab}$ & $116.9 \mathrm{ab}$ & $83.3 \mathrm{ab}$ & $100.8 \mathrm{a}$ & $87.5 \mathrm{a}$ \\
\hline Azoxystrobin $22.9 \%$ & $98.7 \mathrm{ab}$ & $50.0 \mathrm{bc}$ & $33.6 \mathrm{bc}$ & $11.5 \mathrm{~cd}$ & $124.1 \mathrm{a}$ & $131.1 \mathrm{a}$ & $92.4 \mathrm{a}$ & $85.8 \mathrm{a}$ \\
\hline Dimethomorph $43.5 \%$ & $63.6 \mathrm{bc}$ & $40.5 \mathrm{~cd}$ & $22.6 \mathrm{bc}$ & $40.1 \mathrm{bc}$ & $58.2 \mathrm{bcd}$ & $24.8 \mathrm{bcd}$ & $54.0 \mathrm{ab}$ & $104.5 \mathrm{a}$ \\
\hline Fluopicolide $39.5 \%$ & 119.9 a & $22.3 \mathrm{~d}$ & $23.0 \mathrm{bc}$ & $22.8 \mathrm{c}$ & 52.9 cde & $11.2 \mathrm{~cd}$ & $0.0 \mathrm{f}$ & $1.2 \mathrm{e}$ \\
\hline Propamocarb $66.5 \%$ & $39.3 \mathrm{c}$ & $5.8 \mathrm{ef}$ & $0.4 \mathrm{~d}$ & $0.4 \mathrm{~d}$ & $58.5 \mathrm{bcd}$ & $68.4 \mathrm{ab}$ & $0.0 \mathrm{f}$ & $31.3 \mathrm{bc}$ \\
\hline Cymoxanil $25 \%$ + famoxadone $25 \%$ & $6.6 \mathrm{~d}$ & $58.8 \mathrm{bc}$ & $6.8 \mathrm{~cd}$ & $0.6 \mathrm{~d}$ & $59.7 \mathrm{bcd}$ & $89.2 \mathrm{ab}$ & 11.4 cde & $103.5 \mathrm{a}$ \\
\hline Cymoxanil $60 \%$ & n.d. & n.d. & $26.8 \mathrm{bc}$ & $0.9 \mathrm{~d}$ & 45.9 cdef & $41.1 \mathrm{abc}$ & $7.6 \mathrm{cdef}$ & $68.4 \mathrm{ab}$ \\
\hline Ametoctradin $26.9 \%$ + dimethomorph $20.2 \%$ & $7.7 \mathrm{~d}$ & $18.9 \mathrm{de}$ & $41.5 \mathrm{~b}$ & $1.2 \mathrm{~d}$ & $37.2 \mathrm{defg}$ & $11.0 \mathrm{~cd}$ & $18.4 \mathrm{~cd}$ & $10.1 \mathrm{cde}$ \\
\hline Chlorothalonil 54\% & $7.8 \mathrm{~d}$ & $2.7 \mathrm{f}$ & $7.7 \mathrm{~cd}$ & $0.0 \mathrm{~d}$ & 19.7 defgh & $5.0 \mathrm{~d}$ & $9.7 \mathrm{cde}$ & $9.3 \mathrm{cde}$ \\
\hline Mancozeb $66.7 \%$ + zoxamide $8.3 \%$ & $0.0 \mathrm{e}$ & 4.9 ef & $12.2 \mathrm{bcd}$ & $0.0 \mathrm{~d}$ & $11.1 \mathrm{gh}$ & $9.6 \mathrm{~cd}$ & $0.0 \mathrm{f}$ & $16.0 \mathrm{~cd}$ \\
\hline Mancozeb 75\% & n.d. & n.d. & $9.3 \mathrm{bcd}$ & $0.0 \mathrm{~d}$ & $14.5 \mathrm{gh}$ & $3.5 \mathrm{~d}$ & $2.1 \mathrm{def}$ & $6.2 \mathrm{de}$ \\
\hline Cyazofamid $23.3 \%$ & $0.0 \mathrm{e}$ & $2.6 \mathrm{f}$ & $0.7 \mathrm{~d}$ & $0.0 \mathrm{~d}$ & $15.7 \mathrm{efgh}$ & $0.1 \mathrm{~d}$ & $1.2 \mathrm{ef}$ & $0.1 \mathrm{e}$ \\
\hline Fluazinam $40 \%$ & n.d. & n.d. & n.d. & n.d. & $3.2 \mathrm{~h}$ & $6.4 \mathrm{~d}$ & $21.8 \mathrm{bc}$ & $0.6 \mathrm{e}$ \\
\hline
\end{tabular}

y Means shown are least-squares means back-transformed from arcsine-square roots used in the analysis of variance. Means within a column with the same letter are not significantly different, Fisher's protected least significant difference, $P \leq 0.01 ;$ n.d. $=$ not done.

${ }^{\mathrm{z}}$ Fungicides were applied at the rates shown in Table 2,1 day before plants were exposed for $48 \mathrm{~h}$ to natural inoculum in the field. 
treatment (Tables 3 to 7) was tabulated and analyzed, three groups of fungicides were identified (Table 8). The fungicides most likely to be grouped with the water control treatment were mandipropamid and azoxystrobin. Six fungicides were in the group most likely to differ from the water control treatment: cyazofamid, mancozeb + zoxamide, mancozeb, chlorothalonil, fluazinam, and ametoctradin + dimethomorph (Table 8). Dimethomorph, fluopicolide, propamocarb, cymoxanil + famoxadone, and cymoxanil were more likely to group with the water control treatment than cyazofamid but were less likely to group with the water control treatment than mandipropamid.

Likewise, when the number of times fungicide treatments grouped with the most effective fungicides in the eight bioassays was analyzed, four groups of fungicides were identified (Table 9). In this case, in addition to mandipropamid and azoxystrobin, dimethomorph was least likely to be among the most effective fungicides. The group of most effective fungicides included cyazofamid, mancozeb + zoxamide, mancozeb, and chlorothalonil. Fluazinam, which was not significantly different from the most effective fungicides, and cymoxanil, which was not significantly different from the least effective fungicides, did not differ from each other (Table 9). Fluopicolide, propamocarb, cymoxanil + famoxadone, and ametoctradin + dimethomorph differed from cyazofamid and mandipropamid.

Based on relative disease severity values $>50 \%$ that also did not differ significantly from the water control treatment at $P \leq 0.01$, six different fungicide efficacy patterns were observed in this study (Fig. 1). The most frequent pattern, observed three times in July and October 2013, was reduced efficacy of mandipropamid. Five other efficacy patterns were observed one time each. These patterns included reduced efficacy of three, four, or six fungicides. Each pattern included reduced efficacy of mandipropamid and of azoxystrobin. Four of these patterns included reduced efficacy of dimethomorph, three included reduced efficacy of cymoxanil, and two included reduced efficacy of propamocarb.

Sensitivities to several fungicides were associated with each other (Fig. 1). Reduced efficacy of dimethomorph or cymoxanil occurred only when resistance to azoxystrobin was present. Reduced efficacy

Table 7. Increase in severity (\%) of downy mildew on cucumber plants between 5 and 7 days after exposure to natural inoculum of Pseudoperonospora cubensis in July and October 2013 and $2014^{\mathrm{y}}$

\begin{tabular}{|c|c|c|c|c|c|c|c|c|}
\hline \multirow[b]{2}{*}{ Fungicide $^{\mathrm{z}}$} & \multicolumn{2}{|c|}{ July 2013} & \multicolumn{2}{|c|}{ October 2013} & \multicolumn{2}{|c|}{ July 2014} & \multicolumn{2}{|c|}{ October 2014} \\
\hline & Trial 1 & $\overline{\text { Trial } 2}$ & Trial 1 & $\overline{\text { Trial } 2}$ & Trial 1 & $\overline{\text { Trial } 2}$ & Trial 1 & Trial 2 \\
\hline None; water control & $41.5 \mathrm{ab}$ & $42.1 \mathrm{a}$ & $16.5 \mathrm{ab}$ & $1.7 \mathrm{a}$ & $14.2 \mathrm{a}$ & $10.5 \mathrm{a}$ & $20.0 \mathrm{a}$ & $6.6 \mathrm{bc}$ \\
\hline Mandipropamid 23.3\% & $35.0 \mathrm{ab}$ & $28.4 \mathrm{ab}$ & $23.4 \mathrm{a}$ & $1.6 \mathrm{a}$ & $14.9 \mathrm{a}$ & $7.5 \mathrm{a}$ & $7.2 \mathrm{bcd}$ & $11.0 \mathrm{ab}$ \\
\hline Azoxystrobin $22.9 \%$ & $41.6 \mathrm{ab}$ & $21.3 \mathrm{bc}$ & $6.6 \mathrm{c}$ & $0.0 \mathrm{~b}$ & $11.3 \mathrm{ab}$ & $9.2 \mathrm{a}$ & $15.1 \mathrm{ab}$ & $10.5 \mathrm{ab}$ \\
\hline Dimethomorph $43.5 \%$ & $28.3 \mathrm{bc}$ & $21.6 \mathrm{bc}$ & $3.3 \mathrm{~cd}$ & $0.4 \mathrm{ab}$ & $7.6 \mathrm{abc}$ & $0.9 \mathrm{bcd}$ & $8.8 \mathrm{abc}$ & $9.5 \mathrm{ab}$ \\
\hline Fluopicolide $39.5 \%$ & $52.0 \mathrm{a}$ & $13.3 \mathrm{~cd}$ & $5.3 \mathrm{c}$ & $0.0 \mathrm{~b}$ & $11.5 \mathrm{ab}$ & $0.3 \mathrm{~cd}$ & $0.0 \mathrm{f}$ & $0.4 \mathrm{~d}$ \\
\hline Propamocarb $66.5 \%$ & $15.3 \mathrm{c}$ & $3.7 \mathrm{de}$ & $0.1 \mathrm{~d}$ & $0.0 \mathrm{~b}$ & $5.0 \mathrm{abcd}$ & $5.8 \mathrm{ab}$ & $0.0 \mathrm{f}$ & $0.9 \mathrm{~cd}$ \\
\hline Cymoxanil $25 \%+$ famoxadone $25 \%$ & $3.4 \mathrm{~d}$ & $36.8 \mathrm{ab}$ & $1.6 \mathrm{~cd}$ & $0.0 \mathrm{~b}$ & $14.8 \mathrm{a}$ & $5.1 \mathrm{ab}$ & $1.2 \mathrm{def}$ & $18.0 \mathrm{a}$ \\
\hline Cymoxanil $60 \%$ & n.d. & n.d. & $5.3 \mathrm{c}$ & $0.1 \mathrm{~b}$ & $8.6 \mathrm{ab}$ & $3.6 \mathrm{abc}$ & $1.3 \mathrm{def}$ & $11.2 \mathrm{ab}$ \\
\hline Ametoctradin $26.9 \%+$ dimethomorph $20.2 \%$ & $3.0 \mathrm{de}$ & 9.9 cde & $6.9 \mathrm{bc}$ & $0.1 \mathrm{~b}$ & $3.6 \mathrm{bcd}$ & $0.3 \mathrm{~cd}$ & $4.0 \mathrm{cde}$ & $1.6 \mathrm{~cd}$ \\
\hline Chlorothalonil 54\% & $3.5 \mathrm{~d}$ & $2.2 \mathrm{e}$ & $1.5 \mathrm{~cd}$ & $0.0 \mathrm{~b}$ & 4.4 abcd & $1.0 \mathrm{bcd}$ & $2.1 \mathrm{cdef}$ & $1.6 \mathrm{~cd}$ \\
\hline Mancozeb $66.7 \%$ + zoxamide $8.3 \%$ & $0.0 \mathrm{e}$ & $3.1 \mathrm{e}$ & $2.5 \mathrm{~cd}$ & $0.0 \mathrm{~b}$ & $0.9 \mathrm{~cd}$ & $0.1 \mathrm{~cd}$ & $0.0 \mathrm{f}$ & $0.7 \mathrm{~d}$ \\
\hline Mancozeb $75 \%$ & n.d. & n.d. & $1.8 \mathrm{~cd}$ & $0.0 \mathrm{~b}$ & $1.1 \mathrm{~cd}$ & $0.6 \mathrm{~cd}$ & 0.4 ef & $0.9 \mathrm{~cd}$ \\
\hline Cyazofamid $23.3 \%$ & $0.0 \mathrm{e}$ & $1.8 \mathrm{e}$ & $0.1 \mathrm{~d}$ & $0.0 \mathrm{~b}$ & $0.7 \mathrm{~d}$ & $0.0 \mathrm{~d}$ & $0.4 \mathrm{ef}$ & $0.1 \mathrm{~d}$ \\
\hline Fluazinam $40 \%$ & n.d. & n.d. & n.d. & n.d. & $0.0 \mathrm{~d}$ & $1.3 \mathrm{bcd}$ & $3.8 \mathrm{cde}$ & $0.4 \mathrm{~d}$ \\
\hline
\end{tabular}

${ }^{y}$ Increase in severity was calculated by subtracting the percent disease severity at 5 days from the percent disease severity at 7 days. Means shown are leastsquares means back-transformed from arcsine-square roots used in the analysis of variance. Means within a column with the same letter are not significantly different, Fisher's protected least significant difference, $P \leq 0.01 ;$ n.d. $=$ not done.

${ }^{\mathrm{z}}$ Fungicides were applied at the rates shown in Table 2, 1 day before plants were exposed for $48 \mathrm{~h}$ to natural inoculum in the field.

Table 8. Number of times fungicides did not differ from the water control treatment by five measurements of disease in experiments in which fungicide-treated cucumber plants were exposed to natural inoculum of Pseudoperonospora cubensis in July and October 2013 and 2014

\begin{tabular}{|c|c|c|c|c|c|c|c|c|}
\hline Fungicide $^{u}$ & $N^{\mathbf{v}}$ & $\begin{array}{l}\text { Severity } \\
5 \text { days }\end{array}$ & $\begin{array}{l}\text { Severity } \\
7 \text { days }\end{array}$ & $\begin{array}{l}\text { Relative severity } \\
7 \text { days }^{w} \\
\end{array}$ & $\begin{array}{c}\text { Incidence } \\
7 \text { days }\end{array}$ & $\begin{array}{c}\text { Difference } \\
\text { in severities }{ }^{\mathrm{x}}\end{array}$ & $\begin{array}{c}\text { Mean } \\
\text { proportion }^{y}\end{array}$ & $\begin{array}{c}\text { Standard } \\
\text { error }^{\mathbf{z}}\end{array}$ \\
\hline Mandipropamid $23.3 \%$ & 8 & 7 & 8 & 8 & 8 & 7 & 0.86 & $0.055 \mathrm{a}$ \\
\hline Azoxystrobin $22.9 \%$ & 8 & 5 & 5 & 5 & 7 & 5 & 0.64 & $0.076 \mathrm{ab}$ \\
\hline Dimethomorph $43.5 \%$ & 8 & 3 & 3 & 4 & 8 & 5 & 0.56 & $0.079 \mathrm{bc}$ \\
\hline Fluopicolide $39.5 \%$ & 8 & 2 & 2 & 2 & 6 & 2 & 0.38 & 0.077 bcde \\
\hline Propamocarb $66.5 \%$ & 8 & 2 & 2 & 2 & 5 & 3 & 0.38 & 0.077 bcde \\
\hline Cymoxanil $25 \%+$ famoxadone $25 \%$ & 8 & 3 & 3 & 3 & 6 & 4 & 0.48 & $0.079 \mathrm{bcd}$ \\
\hline Cymoxanil $60 \%$ & 6 & 2 & 3 & 3 & 5 & 3 & 0.52 & $0.091 \mathrm{bcd}$ \\
\hline $\begin{array}{l}\text { Ametoctradin } 26.9 \% \text { + dimethomorph } \\
20.2 \%\end{array}$ & 8 & 1 & 0 & 0 & 6 & 2 & 0.28 & $0.071 \mathrm{cdef}$ \\
\hline Chlorothalonil $54 \%$ & 8 & 0 & 0 & 0 & 3 & 2 & 0.20 & $0.063 \mathrm{def}$ \\
\hline Mancozeb $66.7 \%$ + zoxamide $8.3 \%$ & 8 & 0 & 0 & 0 & 3 & 0 & 0.16 & 0.058 ef \\
\hline Mancozeb $75 \%$ & 6 & 0 & 0 & 0 & 2 & 1 & 0.20 & $0.073 \mathrm{def}$ \\
\hline Cyazofamid $23.3 \%$ & 8 & 0 & 0 & 0 & 1 & 0 & 0.12 & $0.051 \mathrm{f}$ \\
\hline Fluazinam $40 \%$ & 4 & 0 & 0 & 0 & 2 & 0 & 0.23 & 0.095 cdef \\
\hline
\end{tabular}

${ }^{\mathrm{u}}$ Fungicides were applied at the rates shown in Table 2, 1 day before plants were exposed for $48 \mathrm{~h}$ to natural inoculum in the field.

v Number of experiments in which the fungicide was tested.

w Severity in fungicide treatments divided by severity in the water control treatment.

x Severity at 5 days subtracted from severity at 7 days.

${ }^{y}$ Likelihood that the fungicide does not differ from the water control treatment. Proportions were back-transformed from the logit of proportions in categorical data analysis. Because a Bayes estimator was used in the analysis in place of the actual proportions to adjust for proportions of 0 and 1.0 , mean proportions differ from arithmetic means calculated from the five measurements of disease.

${ }^{\mathrm{z}}$ Means followed by the same letter are not significantly different, based on contrasts of maximum-likelihood estimates evaluated with $\chi^{2}$ tests, $P \leq 0.01$. 
of fluopicolide occurred only with reduced efficacy of azoxystrobin and dimethomorph. Reduced efficacy of propamocarb occurred only with reduced efficacy of azoxystrobin and cymoxanil. Because of the small number of samples, $\chi^{2}$ analyses comparing pairs of fungicides were nonsignificant, although reduced efficacy of dimethomorph was weakly associated with resistance to azoxystrobin (Fisher's exact test, $P=0.07$; Li et al. 2014).

\section{Discussion}

Severity of cucurbit downy mildew rated 7 days after exposure to natural inoculum of $P$. cubensis and severity relative to the water control treatment calculated with 7-day ratings were judged to be the best measurements of disease to assess fungicide efficacy. Fewer differences among fungicides were detected with incidence than with severity, because disease incidence was a less quantitative measurement of disease in this study than severity. Severity rated 5 days after exposure to inoculum, when overall severity values were smaller than at 7 days, revealed fewer differences among fungicides than severity rated 7 days after exposure. In addition, fungicide treatments did not differ in one bioassay rated at 5 days but differences among fungicide treatments were significant after 7 days in all bioassays. The increase in severity values between 5 and 7 days was $<10 \%$ with most fungicides; therefore, this variable also did not differentiate fungicides as well as severity at 7 days, unless disease was particularly severe (Table 7).

Relative severity of $>50 \%$ was selected as the value to distinguish reduced efficacy from a completely sensitive reaction to a given fungicide, based on the statistical analyses of relative severity across all eight experiments and use of relatively high concentrations of fungicide active ingredients at rates applied in the field. If a larger threshold value was used, such as $>90 \%$, which was used to distinguish isolates of Phytophthora capsici sensitive and resistant to mefenoxam in vitro (Lamour and Hausbeck 2000), then the number of instances of reduced efficacy would be three for mandipropamid, four for azoxystrobin, one for dimethomorph, one for cymoxanil, one for fluopicolide, and zero for propamocarb. Thus, even with a more conservative threshold, reduced efficacy of five fungicides was detected in this study. Pavelková et al. (2014) evaluated sporulation by Pseudoperonospora cubensis on fungicide-treated leaf discs and used a value of $35 \%$ of the maximum value to separate resistant from sensitive isolates. When plants in the current study were rated after incubation at high humidity in some experiments, sporangiophores with sporangia were observed on all symptomatic plants but sporulation was not quantified.

The significant variation between years and seasons observed in this study was not unexpected, based on the results of previous field experiments with cucurbit downy mildew and fungicides. Variation from year to year in the effectiveness of several fungicides included in the current study, such as propamocarb and cymoxanil + famoxadone, has been reported (Adams and Quesada-Ocampo 2014; Adams et al. 2015; Pavelková et al. 2014). When isolates of $P$. cubensis from the Czech Republic were tested with a leaf-disk bioassay, isolates resistant to dimethomorph were detected in 2005, 2006, and 2009 but not in 2007, 2008, and 2010 (Pavelková et al. 2014). In a study with Phytophthora infestans, a decrease in sensitivity to cymoxanil was detected in isolates sampled at the beginning and end of one growing season (Grünwald et al. 2006). Variation in efficacy of fluopicolide was observed between two locations in North Carolina in 2013 (Adams and Quesada-Ocampo 2014; Adams et al. 2014). The differences between bioassays done within the same season within 0 to 5 days of each other, however, were unexpected. Differences between bioassays within seasons may have

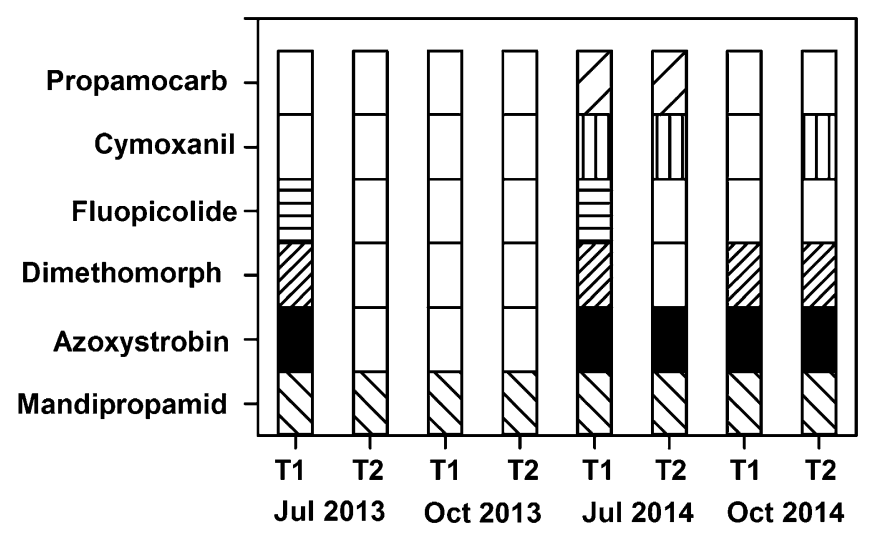

Fig. 1. Reduced efficacy of one or more fungicides in eight experiments with potted cucumber plants treated with recommended rates of fungicides before exposure to natural inoculum of Pseudoperonospora cubensis for $48 \mathrm{~h}$ in Charleston, SC. Patterns represent reduced efficacy of the fungicide in the same row, and blank cells represent efficacy relative to the water control treatment.

Table 9. Number of times fungicides grouped with the best treatments by five measurements of disease in experiments in which fungicide-treated cucumber plants were exposed to natural inoculum of Pseudoperonospora cubensis in July and October 2013 and 2014

\begin{tabular}{|c|c|c|c|c|c|c|c|c|}
\hline Fungicide ${ }^{u}$ & $N^{\mathbf{v}}$ & $\begin{array}{l}\text { Severity } \\
5 \text { days }\end{array}$ & $\begin{array}{l}\text { Severity } \\
7 \text { days }\end{array}$ & $\begin{array}{l}\text { Relative severity } \\
7 \text { days }^{\mathrm{w}}\end{array}$ & $\begin{array}{l}\text { Incidence } \\
7 \text { days }\end{array}$ & $\begin{array}{l}\text { Difference in } \\
\text { severities }^{x}\end{array}$ & $\begin{array}{c}\text { Mean } \\
\text { proportiony }\end{array}$ & $\begin{array}{c}\text { Standard } \\
\text { error }^{\mathbf{z}}\end{array}$ \\
\hline Mandipropamid $23.3 \%$ & 8 & 0 & 0 & 0 & 0 & 0 & 0.10 & $0.0474 \mathrm{~g}$ \\
\hline Azoxystrobin $22.9 \%$ & 8 & 2 & 0 & 1 & 1 & 1 & 0.20 & $0.0632 \mathrm{fg}$ \\
\hline Dimethomorph $43.5 \%$ & 8 & 2 & 1 & 1 & 0 & 2 & 0.22 & $0.0655 \mathrm{efg}$ \\
\hline Fluopicolide $39.5 \%$ & 8 & 5 & 4 & 2 & 2 & 4 & 0.44 & $0.0785 \mathrm{cdef}$ \\
\hline Propamocarb $66.5 \%$ & 8 & 4 & 4 & 4 & 1 & 4 & 0.44 & $0.0785 \mathrm{cdef}$ \\
\hline Cymoxanil $25 \%+$ famoxadone $25 \%$ & 8 & 3 & 3 & 2 & 2 & 3 & 0.36 & $0.0759 \mathrm{def}$ \\
\hline Cymoxanil $60 \%$ & 6 & 3 & 1 & 2 & 1 & 2 & 0.35 & $0.0871 \mathrm{defg}$ \\
\hline $\begin{array}{l}\text { Ametoctradin } 26.9 \%+\text { dimethomorph } \\
20.2 \%\end{array}$ & 8 & 5 & 5 & 3 & 1 & 5 & 0.48 & 0.079 bcde \\
\hline Chlorothalonil 54\% & 8 & 7 & 6 & 6 & 3 & 5 & 0.64 & $0.0759 \mathrm{abc}$ \\
\hline Mancozeb $66.7 \%$ + zoxamide $8.3 \%$ & 8 & 6 & 7 & 7 & 4 & 8 & 0.74 & $0.0694 \mathrm{ab}$ \\
\hline Mancozeb $75 \%$ & 6 & 5 & 6 & 6 & 3 & 5 & 0.75 & $0.0791 \mathrm{ab}$ \\
\hline Cyazofamid $23.3 \%$ & 8 & 7 & 8 & 8 & 7 & 8 & 0.86 & $0.0549 \mathrm{a}$ \\
\hline Fluazinam $40 \%$ & 4 & 3 & 3 & 3 & 2 & 3 & 0.63 & $0.1078 \mathrm{abcd}$ \\
\hline
\end{tabular}

${ }^{\mathrm{u}}$ Fungicides were applied at the rates shown in Table 2, 1 day before plants were exposed for $48 \mathrm{~h}$ to natural inoculum in the field.

v Number of experiments in which the fungicide was tested.

w Severity in fungicide treatments divided by severity in the water control treatment.

x Severity at 5 days subtracted from severity at 7 days.

${ }^{y}$ Likelihood that the fungicide was among the best treatments over all five measures of disease. Proportions were back-transformed from the logit of proportions in categorical data analysis. Because a Bayes estimator was used in the analysis in place of the actual proportions to adjust for proportions of 0 and 1.0 , mean proportions differ from arithmetic means calculated from the five measurements of disease.

${ }^{\mathrm{z}}$ Means followed by the same letter are not significantly different, based on contrasts of maximum-likelihood estimates evaluated with $\chi^{2}$ tests, $P \leq 0.01$. 
been due to genetically different isolates, present on the source plants, infecting the bioassay plants in the two trials. Quesada-Ocampo et al. (2012) placed isolates of Pseudoperonospora cubensis from South Carolina into five different genetic clusters, which indicated a moderate level of diversity. This finding of genetic diversity supports the likelihood that multiple isolates were present in Charleston in at least three of the four seasons: July 2013, July 2014, and October 2014. However, individual isolates were not examined in this study.

Resistance to mandipropamid, a carboxylic acid amine in Fungicide Resistance Action Committee (FRAC) group 40, was detected consistently in all eight experiments with all five disease measurements, except for the increase in severity in trial 1 in October 2014. Thus, one of the initial hypotheses, that mandipropamid would not control downy mildew, was confirmed. Isolates of $P$. cubensis resistant to mandipropamid have been detected since 2007 in multiple locations (Olaya et al. 2009). Likewise, severity of downy mildew on pickling cucumber in Virginia treated with mandipropamid did not differ from the nonsprayed control treatment (Rideout et al. 2014). The consistent detection of resistance to mandipropamid indicates that the potted plant assay can be used to identify fungicide resistance that is frequent within populations of $P$. cubensis.

A high level (i.e., relative disease severity $>90 \%$ ) of reduced efficacy of dimethomorph, another fungicide in FRAC group 40, was observed once, in October 2014, and a moderate level (i.e., relative disease severity $>50 \%$ but $\leq 90 \%$ ) was observed three times in July 2013 and July and October 2014. Dimethomorph applied alone has not been evaluated recently against cucurbit downy mildew in field trials; it was moderately effective in Georgia in 2006 (Langston 2007). Carboxylic acid amides (e.g., mandipropamid and dimethomorph) were significantly less effective than fluopicolide, propamocarb, and cyazofamid between 2000 and 2008 (Ojiambo et al. 2010). Between 5 and $60 \%$ of the isolates of P. cubensis assayed in the Czech Republic between 2005 and 2010 showed reduced sensitivity to field application rates $(450 \mu \mathrm{g} / \mathrm{ml})$ of dimethomorph in 3 of the 6 years (Pavelková et al. 2014). Although cross-resistance was reported for carboxylic acid amide active ingredients, reduced efficacy of dimethomorph was observed only half as often in the current study as reduced efficacy of mandipropamid (Blum et al. 2011).

Ametoctradin was evaluated in a premixture with dimethomorph, because this formulation is the one commercially available. In half of the experiments, ametoctradin + dimethomorph was more effective than dimethomorph alone and, in three other experiments, these two treatments were similarly effective, based on severity ratings at 7 days. Of the six fungicides that were the most effective in this study, ametoctradin + dimethomorph was the only one that did not reduce disease incidence of downy mildew in all experiments. In six previous field experiments, ametoctradin + dimethomorph reduced severity of downy mildew on cucumber compared with the nonsprayed treatment (Adams et al. 2014; Adams and QuesadaOcampo 2014; Adams et al. 2015; Langston and Sanders 2013, 2014; Rideout et al. 2014).

A high level of reduced efficacy of fluopicolide was detected once, in July 2013; a moderate level also was detected in July 2014. The results with fluopicolide matched results from three field experiments in 2013 in North Carolina (Kinston), Michigan, and Georgia, in which fluopicolide failed to control downy mildew on pickling cucumber (Adams and Quesada-Ocampo 2014; Hausbeck and Linderman 2014; Langston and Sanders 2014). Lack of control with fluopicolide also was observed in North Carolina and Georgia in 2012 (Adams et al. 2013; Langston and Sanders 2013). Although fluopicolide was effective in North Carolina (Sampson) and Virginia in 2013, mancozeb, mancozeb + zoxamide, cyazofamid, ametoctradin + dimethomorph, fluazinam, cymoxanil, cymoxanil + famoxadone, propamocarb, and chlorothalonil were significantly more effective (Adams et al. 2014; Rideout et al. 2014). Thus, the very good control provided by fluopicolide in both Charleston trials in October 2014 was unexpected. Recently, resistance to fluopicolide at $10 \mathrm{mg} /$ liter was found in approximately half of a sample of isolates of $P$. cubensis obtained from various states within the United States (P. S. Ojiambo, personal communication). Apparently, the population of $P$. cubensis in the eastern United States currently is a mixture of isolates that are resistant and sensitive to fluopicolide.

Reduced efficacy of propamocarb was evident in both experiments done in July 2014 but not in the other six experiments. Propamocarb controlled downy mildew well on cucumber in field experiments in North Carolina and Michigan in 2013, where it was one of the most effective fungicides in two of the three experiments (Adams and Quesada-Ocampo 2014; Adams et al. 2014; Hausbeck and Linderman 2014). However, in North Carolina in 2014, the level of control by the end of the season was only $14 \%$ relative to the nonsprayed treatment (Adams et al. 2015). In the Czech Republic, 4 to $9 \%$ of the isolates tested showed reduced sensitivity to propamocarb at $1,214 \mu \mathrm{g} / \mathrm{ml}$ (Pavelková et al. 2014).

Resistance to azoxystrobin was detected in five of the eight experiments. Severity of downy mildew on pickling cucumber treated with azoxystrobin or pyraclostrobin did not differ from the nonsprayed control treatment in previous and recent field experiments (Keinath et al. 2008; Langston 2007; Langston and Sanders 2013; McGrath and Fox 2008; Vallad et al. 2015). QoI fungicides were significantly less effective than fluopicolide, propamocarb, and cyazofamid between 2000 and 2008 (Ojiambo et al. 2010). However, azoxystrobin was effective in both bioassays in October 2013, which indicates that QoI-sensitive isolates are still present in the United States.

An isolate or isolates of $P$. cubensis with reduced sensitivities to QoI fungicides (FRAC group 11) and cymoxanil (FRAC group 27) was present in Charleston, SC, in 2014. In three experiments in 2014 (both experiments in July and the second experiment in October), the treatments of cymoxanil + famoxadone, cymoxanil applied alone, and azoxystrobin did not differ from the water control treatment. Famoxadone is a FRAC group 11 fungicide, and there is crossresistance among all QoI fungicides (Brent and Holloman 2007). In all four experiments in 2013, cymoxanil + famoxadone and cymoxanil were effective against downy mildew. Because of significant variation among trials and seasons, it is not clear whether the difference between years with cymoxanil represents a shift toward reduced efficacy against $P$. cubensis. However, in October 2014, lack of efficacy with cymoxanil + famoxadone was detected in a field experiment in Kinston, NC, where final severity with this fungicide did not differ from the nonsprayed treatment (Adams et al. 2015). Between 5 and $95 \%$ of the isolates of $P$. cubensis tested in the Czech Republic between 2005 and 2010 showed reduced sensitivity to cymoxanil at $240 \mu \mathrm{g} / \mathrm{ml}$ (Pavelková et al. 2014).

Reduced efficacy of three or more fungicides was detected in five of the eight experiments. The nature of the bioassay does not enable determining whether a single isolate resistant to multiple fungicides or multiple isolates resistant to single fungicides infected the potted cucumber plants. However, there appeared to be a pattern of reduced efficacy of certain fungicides. Reduced efficacy of dimethomorph, cymoxanil, fluopicolide, and propamocarb occurred only in the presence of resistance to azoxystrobin. Treating plants with different concentrations of fungicides, inoculation with single-sporangium isolates, and incubation under controlled conditions, in addition to testing a large number of isolates, would be necessary to investigate resistance to multiple fungicides further. Recently, 2 of 23 single-sporangium isolates of $P$. cubensis were resistant to both fluopicolide and propamocarb (P. S. Ojiambo, personal communication), which confirms the existence of isolates resistant to two fungicides. Resistance to more than one fungicide in the same isolate may be due to a series of mutations in different resistance genes over time that is more likely to occur in isolates already resistant to one fungicide, as has been proposed to occur in Botrytis cinerea $(\mathrm{Li}$ et al. 2014). If resistance to fungicides in $P$. cubensis develops as rapidly as in Podosphaera xanthii (i.e., within a single growing season), then the appearance of isolates with resistance to multiple fungicides is to be expected (McGrath and Shishkoff 2001).

Resistance to mefenoxam in Phytophthora capsici, another diploid Oomycete, is due to the action of a single incompletely dominant gene (Lamour and Hausbeck 2000). Lamour and Hausbeck 
demonstrated that crossing two isolates with intermediately sensitive phenotypes yielded progeny with the approximate ratio of 1:2:1 sensitive-intermediately sensitive-resistant. This also may be the case with Pseudoperonospora cubensis in the early stages of resistance development, when the largest group of isolates within a population is heterozygous for resistance determined by single genes. A single dominant gene controls resistance to mandipropamid and to azoxystrobin (Blum et al. 2011; Ishii et al. 2001). The presence of oospores in $P$. cubensis may allow genotypes resistant to fungicides to persist from one growing season to another (Cohen et al. 2014; Thomas et al. 2013; Zhang et al. 2012). In addition, the presence of both the A1 and A2 mating types of $P$. cubensis in the eastern United States would allow sexual reproduction between genotypes resistant to different fungicides. Recombination during sexual reproduction may produce new combinations of resistance to multiple fungicides in the population.

In field experiments in other locations that included the six fungicides that were most effective in the current study (i.e., cyazofamid, fluazinam, mancozeb + zoxamide, mancozeb, chlorothalonil, and ametoctradin + dimethomorph), cyazofamid consistently was more effective than mancozeb + zoxamide and ametoctradin + dimethomorph (Adams and Quesada-Ocampo 2014; Adams et al. 2014, 2015; Rideout et al. 2014). In the same studies, there was no consistent difference between mancozeb + zoxamide and ametoctradin + dimethomorph. Because fluazinam is not registered for use on cucumber, it was evaluated in only two studies, where efficacy was similar to mancozeb + zoxamide and ametoctradin + dimethomorph in Georgia (Langston and Sanders 2014) and greater than mancozeb + zoxamide but similar to ametoctradin + dimethomorph and cyazofamid in Virginia (Rideout et al. 2014). The contribution of zoxamide to the performance of mancozeb + zoxamide was not determined in the current study. However, mancozeb + zoxamide did not differ from mancozeb by any measure of disease. In North Carolina, mancozeb + zoxamide was more effective than mancozeb in 2013 but not in 2014, even though downy mildew was severe in both years (Adams and Quesada-Ocampo 2014; Adams et al. 2015).

The fungicides that were most effective at reducing severity of downy mildew also prevented an increase in downy mildew severity between 5 and 7 days after exposure. Some of these fungicides, such as cyazofamid and mancozeb + zoxamide, may be useful later in the season after the pathogen is established on a crop. Cyazofamid's translaminar activity likely limited the extent of leaf colonization by $P$. cubensis (Mitani et al. 2002).

In contrast to these results from South Carolina, when a similar bioassay was done in Ohio in 2014, all nine fungicides, including propamocarb, fluopicolide, and cymoxamil + famoxadone, controlled downy mildew compared with the nonsprayed control treatment (Baysal-Gurel et al. 2015). Results were similar at three locations within Ohio. All fungicides provided $\geq 62 \%$ control compared with the nonsprayed treatment, which had a maximum severity of $24 \%$. Fungicide rates were identical for seven of the eight fungicides tested in Ohio and South Carolina. The main procedural difference was that potted plants were exposed to natural inoculum for $24 \mathrm{~h}$ in Ohio but $48 \mathrm{~h}$ in South Carolina. The longer exposure time likely resulted in more severe disease overall in the bioassays in South Carolina, which may have increased the likelihood of detecting reduced efficacy of fungicides (Ojiambo et al. 2010).

Both protectant fungicides included in this study, chlorothalonil and mancozeb, consistently were among the best preventative fungicide treatments at 5 and 7 days after exposure to $P$. cubensis. Because protectant fungicides are not effective enough to prevent yield loss in cucumber when they are applied season-long, growers must apply other fungicides after downy mildew appears (Adams and Quesada-Ocampo 2014; Colucci et al. 2007). Based on a largescale meta-analysis, mixing protectant fungicides with downymildew-specific fungicides significantly improved control of cucurbit downy mildew (Ojiambo et al. 2010). Tank-mixing fungicides with different active ingredients has long been recommended as an approach to reduce the risk of fungicide resistance (Hobbelen et al. 2011; Mikaberidze et al. 2014; Staub 1991). Because both chlorothalonil and mancozeb have multiple modes of action against oomycetes and fungi, they are ideal tank-mix partners. If mixed with propamocarb, cymoxanil, or fluopicolide, they would provide additional protection of crops if a population with reduced sensitivity was present. At the rates required to prevent infection by $P$. cubensis, chlorothalonil and mancozeb are low-cost fungicides, approximately $\$ 20 /$ ha, relative to most downy-mildewspecific fungicides, which range from $\$ 31$ to $\$ 139 /$ ha. Mancozeb + zoxamide would be the most economical product that combines a protectant with a downy-mildew-specific active ingredient, because it costs approximately $\$ 37 / \mathrm{ha}$.

In conclusion, the potted cucumber bioassay can be used to rapidly assess the efficacy of fungicides against cucurbit downy mildew. This assay detected multiple instances of reduced efficacy of fungicides applied at concentrations recommended for field application over four seasons and 2 years. The six most effective fungicides performed consistently across all experiments. Results obtained with potted plants treated with downy-mildew-specific fungicides generally matched the published results from field fungicide evaluations done recently in other southern states (Adams and QuesadaOcampo 2014; Adams et al. 2014, 2015; Langston and Sanders 2014; Rideout et al. 2014). State extension specialists or county personnel with access to greenhouse facilities could use the bioassay early in the growing season to guide fungicide recommendations over the following several months. Two limitations of the bioassay should be noted. The bioassay tests only the population of $P$. cubensis present when the potted plants are exposed to the inoculum in the field. Isolates arriving in the area later in the season may differ in fungicide sensitivities. On the other hand, the bioassay can illustrate which fungicides should be applied in combination with protectant fungicides in case resistant isolates appear (Ojiambo et al. 2010). Second, some fungicides that were effective as protectants in the bioassays may not control downy mildew when plants are challenged repeatedly by inoculum throughout the growing season. The most effective fungicides identified in this study can be recommended early in the season. Season-long fungicide experiments, however, are necessary to verify which fungicides can be used later in the season.

\section{Acknowledgments}

I thank V. B. DuBose, C. D. Conrad, M. D. Rushton, and C. M. Keinath for technical assistance.

\section{Literature Cited}

Adams, M. L., Ojiambo, P. S., Thornton, A. C., and McIntyre, J. R. 2013. Evaluation of fungicides for control of downy mildew on cucumber, Sampson County 2012. Plant Dis. Manage. Rep. 7:V067. Online publication. doi:10.1094/PDMR07

Adams, M. L., Parada, C. H., and Quesada-Ocampo, L. M. 2015. Evaluation of fungicides for control of downy mildew on cucumber, Kinston I 2014. Plant Dis. Manage. Rep. 9:V081. Online publication. doi:10.1094/PDMR09

Adams, M. L., and Quesada-Ocampo, L. M. 2014. Evaluation of fungicides for control of downy mildew on cucumber, Kinston 2013. Plant Dis. Manage. Rep. 8:V240. Online publication. doi:10.1094/PDMR08

Adams, M. L., Thornton, A. C., and Quesada-Ocampo, L. M. 2014. Evaluation of fungicides for control of downy mildew on cucumber, Sampson County 2013. Plant Dis. Manage. Rep. 8:V238. Online publication. doi:10.1094/PDMR08

Arauz, L. F., Neufeld, K. N., Lloyd, A. L., and Ojiambo, P. S. 2010. Quantitative models for germination and infection of Pseudoperonospora cubensis in response to temperature and duration of leaf wetness. Phytopathology 100: 959-967.

Baysal-Gurel, F., Mera, J. R., and Miller, S. A. 2015. Monitoring Pseudoperonospora cubensis sensitivity to fungicides, 2014. Plant Dis. Manage. Rep. 9:V051. Online publication. doi:10.1094/PDMR09

Blum, M., Waldner, M., Olaya, G., Cohen, Y., Gisi, U., and Sierotzki, H. 2011. Resistance mechanism to carboxylic acid amide fungicides in the cucurbit downy mildew pathogen Pseudoperonospora cubensis. Pest Manage. Sci. 67: 1211-1214.

Brent, K. J., and Holloman, D. W. 2007. Fungicide resistance in crop pathogens: How can it be managed? FRAC Monogr. No. 1, 2nd ed. Fungicide Resistance Action Committee, Croplife International, Brussels, Belgium.

Cohen, Y., Rubin, A. E., Galperin, M., Ploch, S., Runge, F., and Thiens, M. 2014. Seed transmission of Pseudoperonospora cubensis. PLoS One 9:e109766. 
Colucci, S. J., and Holmes, G. J. 2007. Fungicide insensitivity and pathotype determination of Pseudoperonospora cubensis, causal agent of cucurbit downy mildew. (Abstr.) Phytopathology 97:S24.

Colucci, S. J., Thornton, A. C., Adams, M. L., and Holmes, G. J. 2007. Delayed fungicide application to cucumber and the effects on downy mildew severity and yield, 2006. Plant Dis. Manage. Rep. 1:V107. Online publication. doi: 10.1094/PDMR01

Grünwald, N. J., Sturbaum, A. K., Romero Montes, G., Garay Serrano, E., LozoyaSaldaña, H., and Fry, W. E. 2006. Selection for fungicide resistance within a growing season in field populations of Phytophthora infestans at the center of origin. Phytopathology 96:1397-1403.

Hausbeck, M. K., and Linderman, S. D. 2014. Evaluation of fungicides for control of downy mildew of cucumber, 2013. Plant Dis. Manage. Rep. 8:V304. Online publication. doi:10.1094/PDMR08

Hobbelen, P. H. F., Paveley, N. D., and van den Bosch, F. 2011. Delaying selection for fungicide insensitivity by mixing fungicides at a low and high risk of resistance development: A modeling analysis. Phytopathology 101:1224-1233.

Holmes, G. J., Ojiambo, P. S., Hausbeck, M. K., Quesada-Ocampo, L., and Keinath, A. P. 2015. Resurgence of cucurbit downy mildew in the United States: A watershed event for research and extension. Plant Dis. 99:428-441.

Ishii, H., Fraaije, B. A., Sugiyama, T., Noguchi, K., Nishimura, K., Takeda, T., Amano, T., and Hollomon, D. W. 2001. Occurrence and molecular characterization of strobilurin resistance in cucumber powdery mildew and downy mildew. Phytopathology 91:1166-1171.

Keinath, A. P., and DuBose, V. B. 2000. Evaluation of pumpkin cultivars for powdery and downy mildew resistance, virus tolerance, and yield. HortScience 35:281-285.

Keinath, A. P., DuBose, V. B., and Lassiter, A. W. 2008. Evaluation of fungicides to manage downy mildew on pickling cucumber in Charleston, South Carolina, 2007. Plant Dis. Manage. Rep. 2:V024. Online publication. doi: 10.1094/PDMR02

Keinath, A. P., Holmes, G. J., Everts, K. L., Egel, D. S., and Langston, D. B., Jr. 2007. Evaluation of combinations of chlorothalonil with azoxystrobin, harpin, and disease forecasting for control of downy mildew and gummy stem blight on melon. Crop Prot. 26:83-88.

Kemble, J. M., Quesda-Ocampo, L. M., Lewis Ivey, M. L., Jennings, K. M., and Walgenbach, J. F., eds. 2015. Southeastern U.S. Vegetable Crop Handbook. Vance Publishing Corp., Lincolnshire, IL.

Lamour, K. H., and Hausbeck, M. K. 2000. Mefenoxam insensitivity and the sexual stage of Phytophthora capsici in Michigan cucurbit fields. Phytopathology 90: 396-400.

Langston, D. B., Jr. 2007. Evaluation of fungicides and spray programs for control of downy mildew on cucumber in Georgia I, 2006. Plant Dis. Manage. Rep. 1: V168. Online publication. doi:10.1094/PDMR01

Langston, D. B., Jr., and Sanders, F. H., Jr. 2013. Evaluation of fungicides for control of downy mildew on cucumber in Georgia I, 2012. Plant Dis. Manage. Rep. 7:V108. Online publication. doi:10.1094/PDMR07

Langston, D. B., Jr., and Sanders, F. H., Jr. 2014. Fungicide programs for controlling downy mildew on cucumber in Georgia I, 2013. Plant Dis. Manage. Rep. 8:V311. Online publication. doi:10.1094/PDMR08

Li, X., Fernández-Ortuño, D., Chen, S., Grabke, A., Luo, C.-X., Bridges, W. C., and Schnabel, G. 2014. Location-specific fungicide resistance profiles and evidence for stepwise accumulation of resistance in Botrytis cinerea. Plant Dis. 98:1066-1074.

McGrath, M. T., and Fox, G. M. 2008. Assessment of field resistance to pyraclostrobin- and mefenoxam-based fungicides for managing downy mildew in cucumber, 2007. Plant Dis. Manage. Rep. 2:V149. Online publication. doi: 10.1094/PDMR02

McGrath, M. T., and Shishkoff, N. 2001. Resistance to triadimefon and benomyl: Dynamics and impact on managing cucurbit powdery mildew. Plant Dis. 85: $147-154$

Mikaberidze, A., McDonald, B. A., and Bonhoeffer, S. 2014. Can high-risk fungicides be used in mixtures without selecting for fungicide resistance? Phytopathology 104:324-331.

Mitani, S., Araki, S., Yamaguchi, T., Takii, Y., Ohshima, T., and Matsuo, N. 2002. Biological properties of the novel fungicide cyazofamid against Phytophthora infestans on tomato and Pseudoperonospora cubensis on cucumber. Pest Manage. Sci. 58:139-145.

Neufeld, K. N., and Ojiambo, P. S. 2012. Interactive effects of temperature and leaf wetness duration on sporangia germination and infection of cucurbit hosts by Pseudoperonospora cubensis. Plant Dis. 96:345-353.

Ojiambo, P. S., and Holmes, G. J. 2011. Spatiotemporal spread of cucurbit downy mildew in the eastern United States. Phytopathology 101:451-461.

Ojiambo, P. S., Paul, P. A., and Holmes, G. J. 2010. A quantitative review of fungicide efficacy for managing downy mildew in cucurbits. Phytopathology 100:1066-1076.

Olaya, G., Kuhn, P., Hert, A., Holmes, G., and Colucci, S. 2009. Fungicide resistance in cucurbit downy mildew. (Abstr.) Phytopathology 99:S171.

Patterson, C. L. 1989. Effect of downy mildew (Pseudoperonospora cubensis) on sugar content of watermelon. (Abstr.) Phytopathology 79:1162.

Pavelková, J., Lebeda, A., and Sedláková, B. 2014. Efficacy of fosetyl-Al propamocarb, dimethomorph, cymoxanil, metalaxyl and metalaxyl-M in Czech Pseudoperonospora cubensis populations during the years 2005 through 2010. Crop Prot. 60:9-19.

Quesada-Ocampo, L. M., Granke, L. L., Olsen, J., Gutting, H. C., Runge, F. Thines, M., Lebeda, A., and Hausbeck, M. K. 2012. The genetic structure of Pseudoperonospora cubensis populations. Plant Dis. 96:1459-1470.

Rideout, S. L., Waldenmeier, C. M., Sturgis, C. E., Harrison, A. D., McClaskey, J. R., Blake, H. B., and Custis, J. T., Jr. 2014. Evaluation of selected fungicides for the management of downy mildew in pickling cucumber, 2013. Plant Dis. Manage. Rep. 8:V253. Online publication. doi:10.1094/PDMR08

Staub, T. 1991. Fungicide resistance: Practical experience with antiresistance strategies and the role of integrated use. Annu. Rev. Phytopathol. 29: 421-442.

Thomas, A., Carbone, I. and Ojiambo, P. 2013. Occurrence of the A2 mating type of Pseudoperonospora cubensis in the United States. (Abstr.) Phytopathology 103:S2.145.

Vallad, G., Hughes, B., Kalb, S., Adkison, H., Willis, R., and Riniker, A.T. 2015. Evaluation of selected fungicides for management of downy mildew on cucumber, spring 2014. Plant Dis. Manage. Rep. 9:V069. Online publication. doi:10.1094/PDMR09

Zhang, Y., Pu, Z., Zhou, X., Liu, D., Dai, L., and Wang, W. 2012. A study on the overwintering of cucumber downy mildew oospores in China. J. Phytopathol. 160:469-474. 